\title{
ПиріГ Л. МЕДИЦИНА УКРАЇНИ В ДЗЕРКАЛІ ФІЛАТЕЛІЇ / Любомир Пиріг. - К.: ВД «Авіцена», 2013. - 48 с.
}

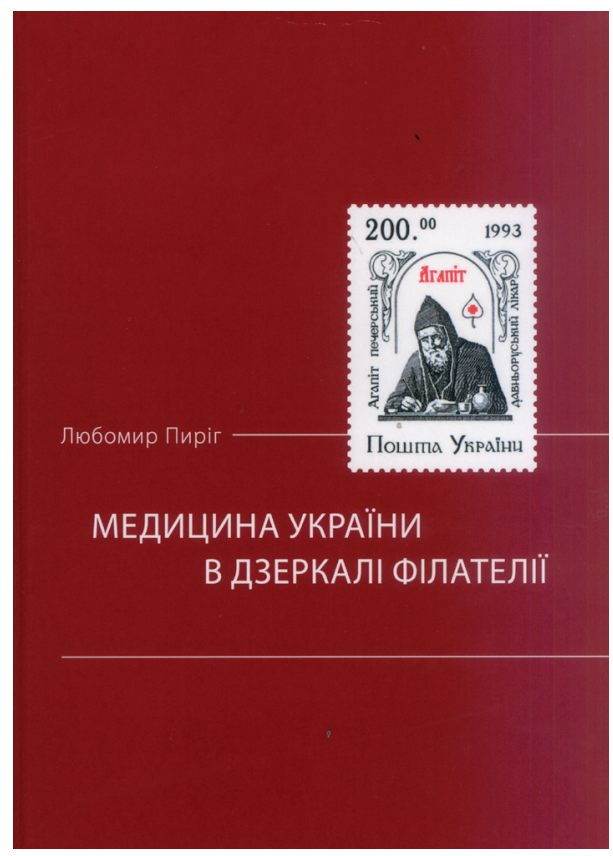

Як відомо, фрілателія належить до дуже популярних різновидів колекціонування. Випуск тематичних поштових марок і конвертів служить одним із засобів популяризації знань. За допомогою фрілателії можна скласти уяву про історію медицини, ії видатних діячів, професійні заклади і події.

Знаний в Україні і далеко за їі межами вчений-нефролог, історик медицини і громадський діяч академік Любомир Антонович Пиріг все своє свідоме життя захоплюється фрілателією, багато його друкованих праць присвячені саме поштовим маркам і конвертам, що пов'язані з Україною і медициною. Відносно недавно побачила світ чергова книжка вченого «Медицина України в дзеркалі фрілателії». Це видання вже привернуло увагу не тільки аматорів фрілателії, а й широкого загалу лікарів і науковців.

На висвітлених марках і конвертах немало портретів видатних українських вчених минувщини, які зробили замітний внесок у розвиток мікробіології, імунології, епідеміології, в організацію медико-санітарної служби, діагностику та терапію інфекційних хвороб. Галерею діячів медицини, яких вшанувала українська фрілателія, відкриває марка, присвячена знаменитому цілителеві Києво-Печерської Лаври
Агапіту Печерському (XI cт.). Саме про цього авторитетного лікаря-монаха вперше згадується в Києво-Печерському патерику, що він лікував відповідним доглядом, харчуванням, травами і молитвою. Маємо достатньо підстав вважати, що серед численних пацієнтів цілителя у той час найбільше було інфекційних хворих, які потребували саме такого лікування.

Увагу читача привертає конверт, присвячений основоположнику епідеміології в Російській імперії, видатному військовому медикові, організаторові медико-санітарної служби, авторові фрундаментального керівництва 3 проблеми чуми Данилові Самойловичу (1744-1805), який був членом 12 зарубіжних академій наук. Ряд марок присвячено видатному імунологу та мікробіологу, батькові фрагоцитарної теорії, лауреату Нобелівської премії Іллі Мечникову (18451916), мікробіологам та епідеміологам Миколі Гамалії (18591949), Григорію Мінху (1835-1896) та Денису Заболотному (1866-1929), а також Володимиру Хавкіну (1860-1930), який свого часу очолював бактеріологічний інститут в Індії, та Івану Савченку(1862-1932), котрий разом з Д. Заболотним створив вакцину від холери. Один з конвертів знайомить 3 українським епідеміологом Левом Громашевським (18871980), який розробив сучасне вчення про механізми передачі збудників інсрекційних хвороб і сформулював основні закони епідеміології.

За допомогою фрілателії представлено шеренгу медиків, які стали відомими поза медициною. Мова йде про відомих письменників Степана Руданського, Остапа Вишню, Василя Стефраника, Антона Чехова, Михайла Булгакова та інших, в їх художніх творах можна знайти опис різних хвороб, зокрема інсрекційних.

Гортаючи сторінки рецензованої книжки академіка Любомира Пирога, можна не тільки розширити власні знання про історію боротьби з іноекційними хворобами, але й отримати велике естетичне задоволення від вдалого дизайну і високої поліграфрічної якості цього видання.

М. Андрейчин, член-кореспондент НАМН України, профресор (м. Тернопіль).

Отримано 3.03.2016 p. 